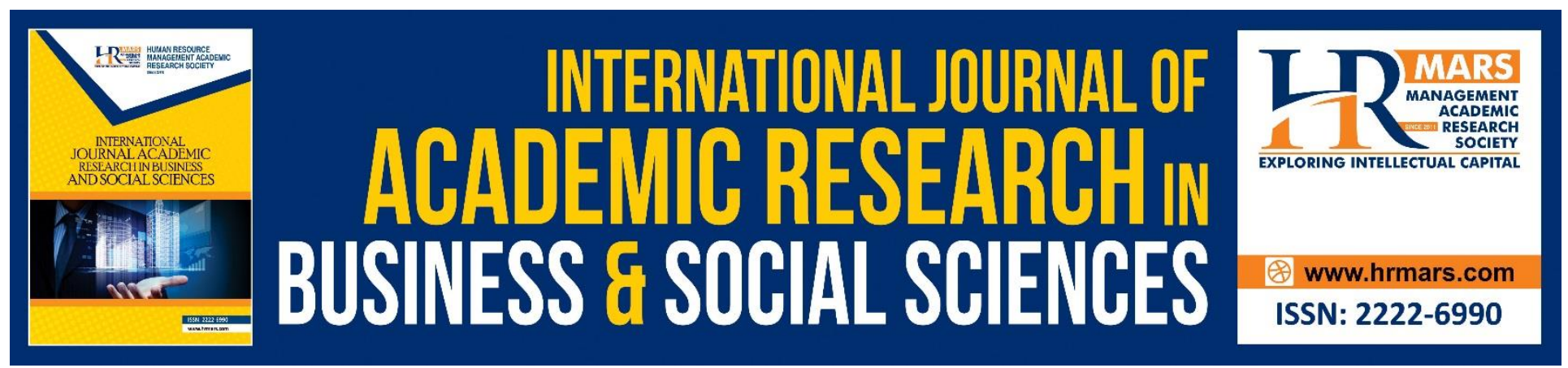

\title{
Statutory and Policy Measures Overcoming Public Information Lock Out in Malaysia
}

Haswira Nor Mohamad Hashim, Nur Asma Yahya, Nurul Shuhada Suhaimi, Anida Mahmood, Fazlin Mohamed Zain

To Link this Article: http://dx.doi.org/10.6007/IJARBSS/v8-i10/5274 DOI: $10.6007 /$ IJARBSS/v8-i10/5274

Received: 12 Sept 2018, Revised: 03 Oct 2018, Accepted: 19 Oct 2018

Published Online: 29 October 2018

In-Text Citation: (Hashim, Yahya, Suhaimi, Mahmood, \& Zain, 2018)

To Cite this Article: Hashim, H. N. M., Yahya, N. A., Suhaimi, N. S., Mahmood, A., \& Zain, F. M. (2018). Statutory and Policy Measures Overcoming Public Information Lock Out in Malaysia. International Journal of Academic Research in Business and Social Sciences, 8(10), 1153-1163.

\section{Copyright: (C) 2018 The Author(s)}

Published by Human Resource Management Academic Research Society (www.hrmars.com)

This article is published under the Creative Commons Attribution (CC BY 4.0) license. Anyone may reproduce, distribute, translate and create derivative works of this article (for both commercial and non-commercial purposes), subject to full attribution to the original publication and authors. The full terms of this license may be seen

at: http://creativecommons.org/licences/by/4.0/legalcode

\section{Vol. 8, No. 10, 2018, Pg. 1153 - 1163}

Full Terms \& Conditions of access and use can be found at http://hrmars.com/index.php/pages/detail/publication-ethics 


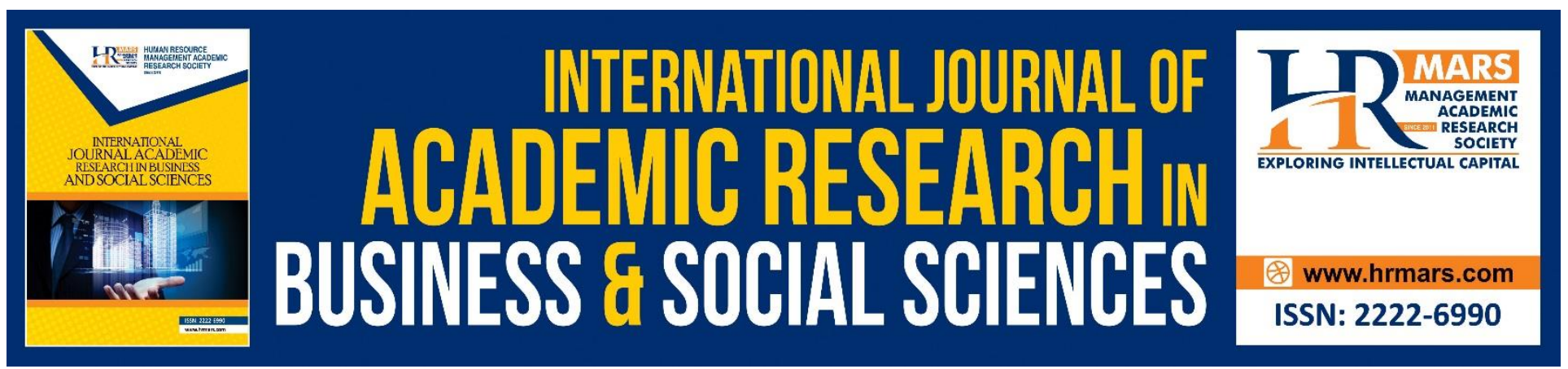

\title{
Statutory and Policy Measures Overcoming Public Information Lock Out in Malaysia
}

\author{
Haswira Nor Mohamad Hashim, Nur Asma Yahya, \\ Nurul Shuhada Suhaimi, Anida Mahmood, Fazlin Mohamed Zain \\ Faculty of Law, UiTM Shah Alam, Selangor, Malaysia
}

\begin{abstract}
This paper reports a study which proposed statutory and policy measures overcoming public information lock out in Malaysia. Public information lock out refers to the presence of the laws which impede the citizens' right to seek public sector information. In the absence of constitutional guarantee and sui generis right to information law, the citizens' right to seek public sector information could be impeded by existing legislation, in particular Malaysian Communications and Multimedia Act 1998. The Act empowers the Commissioner and the Minister to prohibit public access to online contents under s 211(1) and s 266(1)(c). Similarly, Copyright Act 1987 vests in the Government with the exclusive right to control public access to PSI through technological protection measure (s 36A). The study compared the laws and policies in the UK, Canada and New Zealand in order to identify the statutory and policy measures overcoming public information lock out. A cross-sectional survey was also conducted among 40 respondents from government agency, independent statutory body, civil society and academia. The findings of the survey help to provide an insight on the most appropriate statutory and policy measures in overcoming public information lock out in Malaysia.
\end{abstract}

Keywords: Information Lock Out, Right To Information, Public Sector Information, Law And Policy

\section{INTRODUCTION}

The study focused on the legal impediments to citizens' right to information in Malaysia in the form of public information lock out which impede the citizens' right to seek public sector information. 'Public Sector Information' (PSI) refers to information produced or held by government or for government under a law or in connection with official function, business or affair (OECD, 2006). The term "Government" includes the Ministers, the government body/agency and the government employees at federal, state and local government levels (Lor \& Britz, 2007). Citizens have a right to information, which empowers the citizen with the right to seek PSI (Mishra, 2013). The government is under obligation to facilitate citizens' right to seek PSI in accordance to Article 19 of the International Covenant on Civil and Political Rights. 
In assessing the state of the right to information in Malaysia, there is yet a suigeneris law that provides a formal, functioning system that respects, ensures, protects and promotes citizens' right to seek PSI. Neither there is a constitutional guarantee for the right to seek PSI as there is no express provision on the right to information in any part of the Malaysian Federal Constitution (Izwan, 2014). Further, existing laws in particular Communications and Multimedia Act 1998 (MCMA 1998) could be exploited by the public authority to impede citizens' right to seek PSI.

Section 211(1) MCMA 1998 empowers the Communications and Multimedia Commission to issue a prohibition order against online contents regarded by the Commission among others as false, menacing or offensive in character. Further, s 266(1)(c), MCMA 1998 empowers a Minister in the interest of public safety, issues an order that any communication or class of communications to or from any licensee, person or the general public relating to any specified subject shall not be communicated to public. In addition, s 266(2) MCMA 1998 provides that, a certificate signed by the Yang di-Pertuan Agong shall be conclusive proof that the order was made in the interest of public safety.

While arguably s 211(1) and s 266(1) MCMA 1998 promote maturity, responsibilities and accountabilities for internet users, the problem lies in the interpretation and the usage of these sections. What constitutes as "false, menacing, or offensive in character" or what is regarded as "in the interest of public safety" is left to interpretation of the Commission or the Minister. It was argued that the Commission and the Minister should not give broad interpretation to these words so as to impede citizens' right to information (Hashim, 2016). A report published by Article 19 (2017) found that the MCMA 1998 creates a number of overly broad content-related offences. The report proposed for $s 211$ to be revised to narrowly and precisely define what qualifies as prohibited content, in line with the international law.

Another report by Malaysian National Human Rights Society (2016) revealed that 399 websites were blocked through various orders issued under the MCMA 1998 between the year of 2015 and 2016. It also was reported that, in February 2016, an order under the MCMA 1998 was issued to block public access to an online news portal allegedly for causing public confusion, without identifying the offending publication by the online news portal that may violate this provision (Thiru, 2016; Freedom House, 2017).

Public information lock out also occurs due to exclusive rights enjoyed by the government under s 11(1) of the Copyright Act 1987 (CA 1987). As copyright owner, the government has the exclusive right to control the reproduction and communication to the public copyright works including those works which contain PSI (see, ss 13(1)(a)\&(aa) CA 1987). By virtue of s 36A, the government also could use technology protection measures to lock up copyrighted works which contain PSI from being accessed online by the public. All these legal provisions have the effect of impeding citizens' right to seek PSI.

Due to the above legal situations, Malaysian civil society urged for the right to information law which is consistent with international standards to be introduced as a matter of priority (Fernandez, 2016; Yong, 2016). Human Rights Commission of Malaysia's report on the "Round Table Discussion on Access to Information in Malaysia" held in August 2017 noted that the need for information to be freely accessible is vital to create a transparent and open society. 
Hence, it high time for statutory and policy measures overcoming public information lock out to be proposed in Malaysia. The proposed statutory and policy measures should not focus on enacting a sui generis law per se as it is deemed insufficient, but also must also ensure that the exercise of the right is not hindered by the impeding laws. Proposals will be made for legal provisions which impede citizens' right to seek PSI to be revised or repealed through appropriate statutory and policy measures.

\section{METHOD}

The study employed a mixed modes approach involving field work and library based research. The research methodology was designed to answer a two-tier research questions: i) What are statutory and policy measures most appropriate overcoming public information lock out?; and ii) How should the statutory and policy measures be adapted overcoming public information lock out in Malaysia?.

Survey questionnaires was used as an instrument to answer the first research question. The survey questionnaires are divided into seven separate sections. The first section was designed with the purpose of obtaining the demographic information of the respondents by using nominal data. The section which surveyed on statutory and policy measures on information lock-down contains 10variables, based on five-point Likert scale ranging from the lowest to the highest (1=Strongly Disagree, 2=Disagree, 3=Not Sure, 4=Agree, 5=Strongly Agree). The variables were derived from the statutory and policy measures overcoming public information lock out which are currently adopted in other Common Law countries.

For the purpose of comparison, the UK, Canada and New Zealand were selected as sample countries. These three countries are the best countries for the purpose of comparison with Malaysia since they share similar legal system with Malaysia and at the same time. However, unlike Malaysia, these countries have taken appropriate statutory and policy measures overcoming legal impediments to citizens' right to information.

As for the survey, the target population for the survey are representatives of the government agency, independent statutory body, civil society and academia. A stratified, purposive sampling is used to select the respondents among the target population. The criteria for selections are officers at the Attorney General's Chambers and Malaysian Anti-Corruption Commission, as well as civil rights activists and academics experts in constitutional and human rights laws, who are likely to generate useful data for this research.

Data collection for this research adopts mixed-modes approach comprising field and library based research. Secondary data was drawn from primary legal sources in the form of statutes and codes (collectively referred as 'the Laws") and policy, procedures and guidelines (collectively referred as "the Policies"). The laws and policies were collected from the official websites of the government of selected countries. Altogether 7 laws and 4 policies from the UK, Canada and New Zealand were collected for analysis.

For primary data, a cross-sectional data was collected from the survey population. Data collection was conducted between 1 January 2017 until 1 April 2017. Survey was conducted with 20 respondents from the Attorney General's Chambers and Malaysian Anti-Corruption Commission. For the purpose of triangulation, 20 respondents who are civil rights activists and experts in constitutional and human rights law were also surveyed. Self-administered survey questionnaires were distributed 
to the target population by hand using stratified, purposive sampling techniques. The language of instruction for the survey is English. Each respondent was allocated approximately thirty minutes to answer the questionnaires. The completed questionnaires were then collected by the researchers themselves.

For qualitative data, a legal, doctrinal and policy analysis were made on the primary and secondary legal sources. A normative analysis approach to determine what the laws and policies ought to be, was applied in order to answer the second research question. The normative analysis approach is important as the aim of this study is to propose statutory and policy measures overcoming public information lock out in Malaysia. As for quantitative data, the survey data was analyzed using descriptive analysis. The nominal data was analyzed to find the Mode. The ordinal data was statistically analyzed to rank and to find the Median for each variables in the Likert scale and the Mean was used to describe the scale.

\section{RESULTS AND DISCUSSION}

Statutory And Policy Measures Most Appropriate Overcoming Public Information Lock Out The figures below illustrate the findings of the survey conducted with 40 respondents for the purpose of determining statutory and policy measures most appropriate overcoming information lock out in Malaysia. The summary of the analysis is presented in Table and Figure(s).

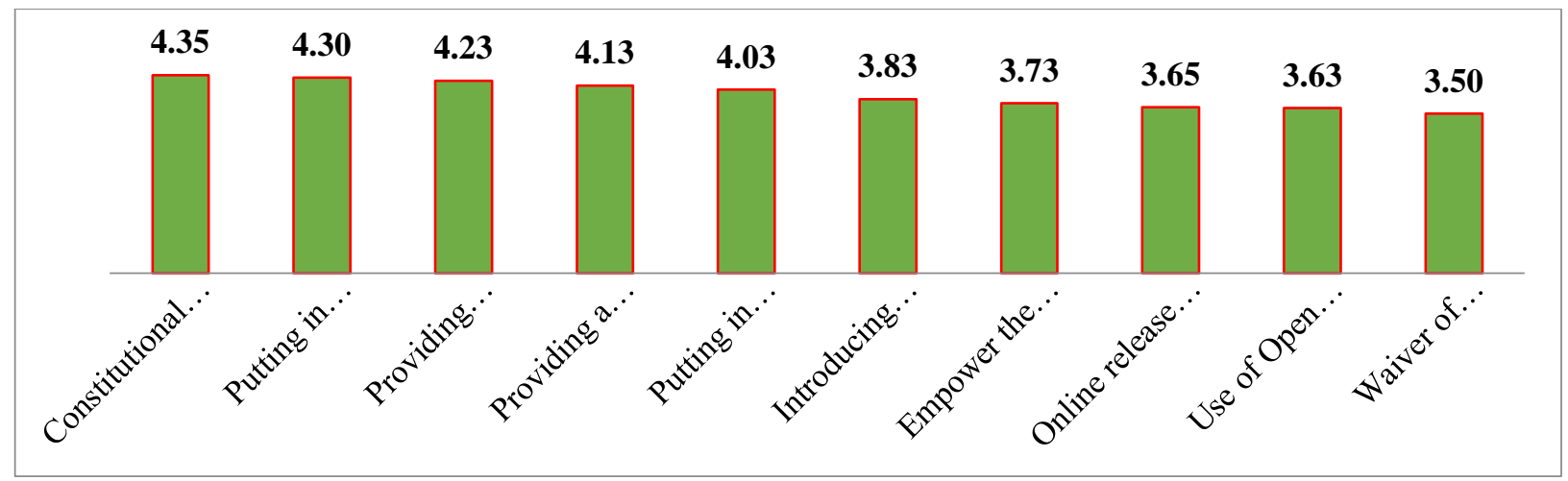

Figure 1. Mean Score on Items Related to Statutory and Policy Measures Overcoming Public Information Lock Out

Based on the descriptive analysis, it is found that the highest Mean value is 4.35 (Constitutional protection of the right to seek information) followed by 4.30 (Putting in place complaint/appeal procedures for violation of the right to seek information). The lowest Mean value is 3.50 (Waiver of Crown copyright). There are 5 variables which recorded a Mean value above 4.00, while 5 others recorded Mean values between 3.50 to 3.83. The Mean values for all the variables surveyed range between 3.50 to 4.35 . The findings indicate that the respondents of this survey are not fully agreeable as to the appropriateness of some of the statutory and policy measures overcoming public information lock out in Malaysia.

Table 1. Total Median of 10 items measuring statutory and policy measures overcoming public information lock out based on the organisation the respondents are attached with. 


\begin{tabular}{|c|c|c|c|c|}
\hline & \multicolumn{4}{|c|}{ Organization Attached With } \\
\hline & $\begin{array}{l}\text { Govt. } \\
\text { Agency }\end{array}$ & $\begin{array}{l}\text { Statuto } \\
\text { ry Body }\end{array}$ & $\begin{array}{l}\text { Civil } \\
\text { Societ } \\
y\end{array}$ & $\begin{array}{l}\text { Academi } \\
\text { a }\end{array}$ \\
\hline $\begin{array}{l}\text { Constitutional protection of the right to seek } \\
\text { information }\end{array}$ & 4.00 & 4.50 & 5.00 & 4.00 \\
\hline $\begin{array}{l}\text { Putting in place complaint/appeal procedures for } \\
\text { violation of the right to seek information }\end{array}$ & 4.00 & 4.00 & 4.50 & 4.00 \\
\hline $\begin{array}{l}\text { Providing statutory right to request and access official } \\
\text { information or information held by public authority }\end{array}$ & 4.00 & 4.00 & 4.00 & 4.00 \\
\hline $\begin{array}{l}\text { Providing a clear public domain notice for information } \\
\text { contained in non-copyrighted material }\end{array}$ & 3.00 & 3.50 & 3.50 & 4.00 \\
\hline $\begin{array}{l}\text { Putting in place complaints procedure for unfair use } \\
\text { of Technological Protection Measures in copyright } \\
\text { works }\end{array}$ & 3.00 & 4.00 & 4.00 & 3.00 \\
\hline Introducing open government initiative for PSI & 3.50 & 3.50 & 4.00 & 4.00 \\
\hline $\begin{array}{l}\text { Empower the Minister, Parliamentary Committee to } \\
\text { amend/repeal conflicting legal provisions }\end{array}$ & 3.00 & 3.00 & 4.00 & 4.00 \\
\hline $\begin{array}{l}\text { Online release of government data and information } \\
\text { including those which are copyrighted }\end{array}$ & 3.50 & 4.00 & 4.00 & 4.00 \\
\hline $\begin{array}{l}\text { Use of Open Government Licence/Creative Commons } \\
\text { Licence for government's copyright works }\end{array}$ & 4.00 & 4.00 & 4.00 & 4.00 \\
\hline Waiver of Crown copyright & 4.00 & 4.50 & 4.00 & 4.00 \\
\hline
\end{tabular}

Analysis of Median value based on organization attached, found that a Median value lower than 4.00 is recorded from the respondents attached to the government agency for 5 variables: i) Providing a clear public domain notice for information contained in non-copyrighted material (3.00); ii) Putting in place complaints procedure for unfair use of Technological Protection Measures in copyright works (3.00); iii) Introducing open government initiative for PSI (3.50); iv) Empower the Minister, Parliamentary Committee to amend/repeal conflicting legal provisions (3.50); and v) Online release of government data and information including those which are copyrighted.

As for the respondents representing independent statutory body, Median values lower than 4.00 are recoded for 3 variables i) Providing a clear public domain notice for information contained in non-copyrighted material (3.50); ii) Introducing open government initiative for PSI (3.50); and iii) Empower the Minister, Parliamentary Committee to amend/repeal conflicting legal provisions (3.00). As for respondents representing civil society, Median values for 9 variables are 4.00 and above, with 1 variable records Median value 5.00 i.e. Constitutional protection of the right to seek information. A high Median value is also recorded from the academia, where Median value 4.00 is recorded for 9 variables. Therefore, it can be concluded that, the academia and civil rights activists are more receptive to the statutory and policy measures overcoming public information lock out compared to the respondents who are attached to government agency and independent statutory body. 
INTERNATIONAL JOURNAL OF ACADEMIC RESEARCH IN BUSINESS AND SOCIAL SCIENCES Vol. 8, No. 10, Oct. 2018, E-ISSN: 222 2-6990 @ 2018 HRMARS

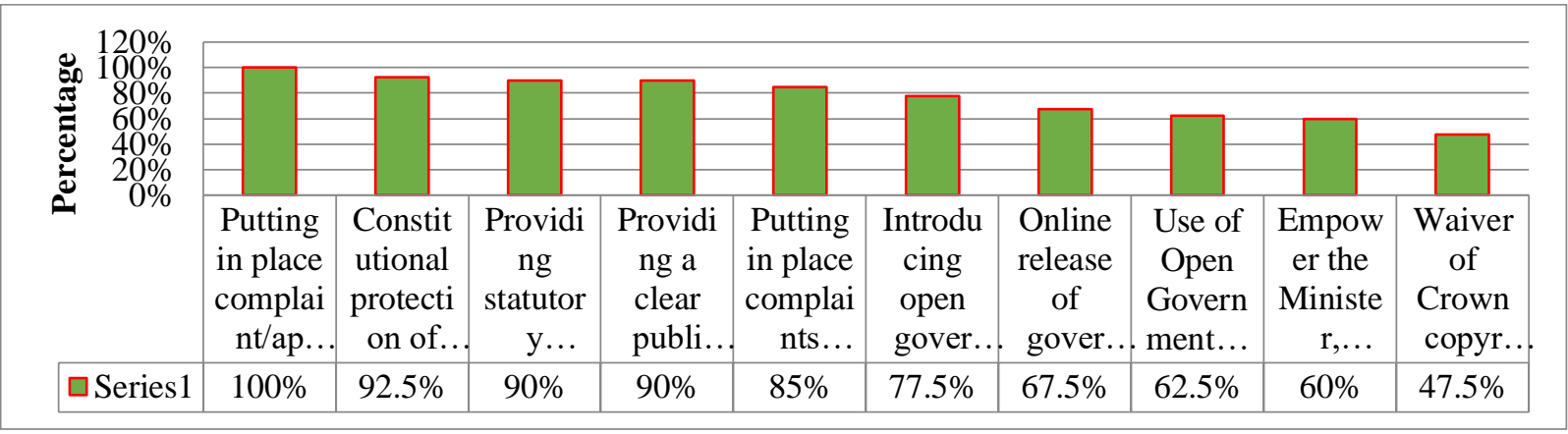

Figure 2. Distribution of percentage agreement of 11 items measuring statutory and policy measures overcoming public information lock out.

In terms of Mode value for each variable, Putting in place complaint/appeal procedures for violation of the right to seek information records the highest Mode value of "Agree and Strongly Agree" at $100.0 \%$. Two variables, i) Providing statutory right to request and access official information or information held by public authority; and ii) Providing a clear public domain notice for information contained in non-copyrighted material record a Mode value of $90.0 \%$. The lowest Mode value for "Agree and Strongly Agree" response is Waiver of Crown copyright (47.5\%). From the above findings, this study observes that overall, majority of the respondents either "Agree" or "Strongly Agree" as to the appropriateness of the statutory and policy measures overcoming public information lock out.

\section{Statutory And Policy Measures Overcoming Public Information Lock Out In Malaysia}

The main purpose of proposing the statutory and policy measures is to overcome public information lock out in Malaysia. The proposed statutory and policy measures are adapted from the findings of the survey reported above. The variables which record high Mean, Median and Mode values are incorporated into the proposal. Besides the survey findings, established principles of right to information and expert opinion are also incorporated in the proposal.

Table 2. Statutory And Policy Measures Overcoming Public Information Lock Out In Malaysia

Action Plan Statutory Measures

To amend Article 10, Federal Constitutional

- To introduce a sui generis right to information legislation which respects, ensures, protects and
To adapt Art 14, Bill of Rights 1990 (NZ) by inserting a provision that protects constitutional right to seek information.

To adapt s 1(1)(a)\&(b), Freedom of Information Act (FOIA) 2000 (UK); s 2(1), s 4(1)(a)\&(b), Access to Information Act (AIA) 1985 (Canada); s 12(1)(a)-(e),
Policy Measures

$$
\text { N/A }
$$

- To adapt para 6.1, UK Government Licensing Framework 2016 which applies Open Government 
promotes citizens' right to seek PSI

- To implement Open Government initiative for PSI
Official Information Act (OIA) 1982 (NZ), to empower the citizens, permanent residents and body corporate with the right to request and to access to information held by public authority and information or latest edition of government's publication.

- To review the power vested under s 211(1) Malaysian

Communications and Multimedia Act 1998 (MCMA 1998) which allows the Minister/Commission to issue prohibition order against online contents declared as false, menacing, offensive in character, without having to identify the offending publication or providing substantiated reasons. FOIA 2000 (UK) which provides
- To adapt the proposal contained in a report by Article 19 for s 211 to be revised to more narrowly and precisely define what qualifies as prohibited content under the MCMA 1998.

- To insert a provision which requires a prohibition order under s 211(1) to specifically identify the online content or online publication which is alleged as false, menacing or offensive.

- To adapt s 501(1) \& s 57(1), the right to file complaint to the Information Commissioner and the right to appeal before a Tribunal.

- To adapt s 41, AIA 1985 (Canada) which provides the right to apply to the Court for a review of the results of an investigation of a complaint by the Information Commissioner.

- To adapt s 24(2) AIA 1985 which requires Parliamentary Committee to be established to review statutory prohibitions set out in the Act.
Licence for public sector data and information.

- To adapt para 2.1, NZ Government Open Access \& Licensing which requires government agencies to make their copyright works available on the most open of licensing terms available.

To adapt the three-part test under Principle 1: Freedom of Opinion, Expression and Information as follows:

- Principle 1.1: Any restriction on expression or information must be prescribed by law. Principle 1.2: Any restriction on expression or information which is sought to be justified on the ground that it protects the reputations of others, must have the genuine purpose and demonstrable effect of protecting a legitimate reputation interest.

- Principle 1.3: A restriction on freedom of expression or information, including to protect the reputations of others, cannot be justified unless it can convincingly be established that it is necessary in a democratic society. 
- To amend s 266(1)(c) - To adapt suggestion by Yong Malaysian

Communications and Multimedia Act 1998 which empowers a Minister to block access of any communication or class of communications to the general public relating to any specified subject in the interest of public safety, with a certificate issued by the Yang di-Pertuan Agong under s 266(2) shall be conclusive proof.

- To amend s 26(3) Copyright Act 1987 which provides that, copyright in every work which is made by or under the direction or control of the Government and its organization. conferred under $s 11$, vest initially in the Government and Government organization and not in the author.

- To introduce Public Domain notice policy.

- To adopt Open Government Licence/Creative Commons Licence for government's copyright works

- To amend ss 36A(1)(a)\&(b)) CA 1987 which enables the Government to use (2016), to remove the Minister's power to block public access to online information and to require Communications and Multimedia Commission to apply to court for an order to block access.

- To adapt s 28(1)(a)-(d), OIA 1982 (NZ) which empowers review by Ombudsmen body of the decisions made by the Minister/Commission. copyright in any:

- Bill, Act. Regulations, By laws;

- Judgments of court or tribunal;

- Reports of Royal commissions, Ministerial or Statutory Inquiries; or Reports of any inquiry.

To adapt s 226D(1) \& (2), - To adapt para 2(b)(i) NZ Copyright Act 1994 (NZ) which Government Open Access provides waiver of Crown Licensing Framework (NZGOAL) and para 6.1, Open Government Licence 2016 (UK) which adopt Creative Commons licences (CCBY) for Government agencies' copyright works.

- To adapt para 2(b)(ii) NZGOAL which requires the government agencies to provide Public Domain notice with clear "no known rights" statements for non-copyright material.

- To adapt para 6.2 Directive 2014 (Canada) and para 21 NZGOAL which requires the Government data and 


$\begin{array}{ll}\text { technology protection } & \text { information to be released } \\ \text { measures to lock up } & \begin{array}{l}\text { online in accessible and } \\ \text { reusable formats through } \\ \text { copyrighted works which } \\ \text { contain public information } \\ \text { from being accessed online } \\ \text { by the public. }\end{array} \\ \text { - To enable online release of } & \text { To adapt Guidance on } \\ \text { government data and } & \text { Technological Protection } \\ \text { information } & \text { Measures Complaints } \\ \text { - To introduce complaints } & \text { Process 2014 (UK) enabling } \\ \text { procedure for unfair use of } & \text { Malaysian citizens unable } \\ \text { Technological Protection } & \text { to access PSI due to the } \\ \text { Measures (TPM) } & \text { application of TPM to file a } \\ \text { complaint to }\end{array}$

\section{CONCLUSION}

The study has achieved its aim to propose statutory and policy measures overcoming public information lock out in Malaysia. The statutory and policy measures proposed by this study are of international standard as the measures were adapted from the UK, Canada and New Zealand. Since the proposal comprised both statutory and policy measures, it serves as authoritative implementation tools overcoming public information lock out in Malaysia. The implementation of the statutory and policy measures requires the Federal Constitution and impeding statutes to be amended, and new legislation and policies to be introduced.

Due to time and budget constraints, the comparative analysis by this study only covers three countries and its survey only involves 40 respondents. In future, the comparative analysis could be expanded to include ASEAN and non-Commonwealth countries particularly USA. The survey also could be expanded to government agencies, statutory bodies, civil societies and academic institutions not covered by this study. Future research should focus on overcoming information lock up and information lock down which impede citizens' right to receive and impart PSI.

Being a legal study, the study did not conduct feasibility study to carry out the statutory and policy measures. However, since data and information in present day mostly exist in digital format, it is anticipated that PSI can be accessed online, hence more costs efficient. The study also did not investigate attitude and readiness among legislatures and the civil servants, being the main stakeholders in passing and implementing the legal and policy frameworks. Hence, further study should be conducted to fill in the gaps left by this study.

\section{ACKNOWLEDGEMENTS}

This paper is derived from a research supported by Universiti Teknologi MARA (UiTM) titled “Legislative Framework to Overcome Legal Impediments To Citizens' Right To Public Information In Malaysia" (2016). The writers thank UiTM for awarding the research grant with the project code 600IRMI/DANA 5/3/LESTARI (0159/2016). 
INTERNATIONAL JOURNAL OF ACADEMIC RESEARCH IN BUSINESS AND SOCIAL SCIENCES

Vol. 8, No. 10, Oct. 2018, E-ISSN: 2222-6990 ㄷ 2018 HRMARS

\section{REFERENCES}

Article 19, (2017). The Communications and Multimedia Act 1998: Legal Analysis. Retrieved from https://www.article19.org/data/files/medialibrary/38690/Malaysia-analysis-Final-December.pdf

Fernandez, J. (2016). Hindraf Calls for Freedom of Information Act. Retrieved from http://www.freemalaysiatoday.com/category/nation/2016/02/08/hindraf-calls-for-freedom-ofinformation-act/

Freedom House, (2017). Freedom on the Net 2016 : Malaysia Country Profile. Retrieved from https://freedomhouse.org/report/freedom-net/2016/malaysia

Hashim, S. (2016). Section 211 and 233 of the Communication and Multimedia Act 1998: A Double Edges Sword. Retrieved from http://shahrinhashim.blogspot.my/2016/07/section-211-and-233of-communication.html

Lor, P. J., \& Britz, J. J. (2007). Is a Knowledge Society Possible Without Freedom of Access To Information? Journal of Information Science, 33(4), 387-397.

Muhamad Izwan, I. (2014). Legal Hurdles in Freedom of Information in Malaysia. http://dx.doi.org/10.2139/ssrn.2470291

Mishra, A. (2013). Right to Information Empowerment or Abuse. Retrieved from http://lawmantra.co.in/right-to-information-empowerment-or-abuse-2/

National Human Rights Society, (2016). Media Access Block. Retrieved from http://hakam.org.my/wp/index.php/tag/media-access-block/

OECD. (2006). Digital Broadband Content: Public Sector Information and Content. Retrieved from http://www.oecd.org/sti/ieconomy/36481524.pdf

Haswira Nor Mohamad Hashim

CORRESPONDING AUTHOR

Email: haswira648@salam.uitm.edu.my 